\title{
The COVID-19 Pandemic: Female Workers' Social Sustainability in Global Supply Chains
}

\author{
Aymen Sajjad *(D) and Gabriel Eweje (D) \\ School of Management, Massey University, Auckland 0632, New Zealand; g.eweje@massey.ac.nz \\ * Correspondence: a.sajjad@massey.ac.nz
}

Citation: Sajjad, A.; Eweje, G. The COVID-19 Pandemic: Female Workers' Social Sustainability in Global Supply Chains. Sustainability 2021, 13, 12565. https://doi.org/ $10.3390 /$ su132212565

Academic Editor: Andrea Appolloni

Received: 29 October 2021

Accepted: 10 November 2021

Published: 14 November 2021

Publisher's Note: MDPI stays neutral with regard to jurisdictional claims in published maps and institutional affiliations.

Copyright: (c) 2021 by the authors. Licensee MDPI, Basel, Switzerland. This article is an open access article distributed under the terms and conditions of the Creative Commons Attribution (CC BY) license (https:/ / creativecommons.org/licenses/by/ $4.0 /)$.
Abstract: This review article investigates the effects of the COVID-19 pandemic on female workers in the global supply chain context. To this end, we reviewed and critically examined emerging scholarly literature as well as policy documents and reports published by international development organizations concerning female workers' social sustainability, livelihood, and health and wellbeing issues in global supply chain operations. Thus, this article focuses on female workers' issues in emerging and developing economies where the ongoing pandemic continues to devastate and create multidimensional social and economic challenges for the wellbeing and social sustainability of female workers. Our analysis suggests that female workers are facing serious socioeconomic challenges that continue to affect their wellbeing, mental health, and livelihoods. Accordingly, it is imperative that international development organizations, non-governmental organizations (NGOs), trade associations, governments, and most importantly the corporate sector not only consider individual responsibility for promoting female workforce social sustainability in global supply chains but also actively collaborate to address pressing social sustainability issues vis à vis female workers. Building on these findings, the implications for future research, practice, and policies are discussed.

Keywords: COVID-19; female workers; gender; social sustainability; global supply chains; wellbeing; multi-stakeholder collaboration

\section{Introduction}

The COVID-19 pandemic has caused a twin threat to the lives and livelihoods of the global population, affecting over 210 nations and regions around the globe. In particular, the COVID-19 pandemic has seriously obstructed the progress in global sustainable development and continues to jeopardize the current advancements made in relation to the implementation of the United Nations' sustainable development goals (SDGs) [1]. From a sustainability perspective, it is imperative to integrate social and environmental aspects into global supply chain operations. According to the Chartered Institute of Procurement and Supply, "global supply chains are networks that can span across multiple continents and countries for the purpose of sourcing and supplying goods and services. Global supply chains involve the flow of information, processes and resources across the globe" [2] (para. 1). Some scholars have noted that global supply chains are relatively risky, vulnerable, and more prone to disruptions than domestic supply chains due to the diverse and intricate linkages between firms operating in these supply chains [3,4]. Thus, as the COVID-19 outbreak is a global crisis, it has disrupted supply chain operations in almost all countries and continues to pose risks from supply and demand shocks $[5,6]$. These disruptions and risks are due to a range of factors including contraction of consumer demand, container shortages, rise in shipping costs, worker shortages, and other critical supply chain bottlenecks such as congestion and blockages in production systems [7-9]. In addition, there was a lack of preparedness on the part of many companies to tackle supply chain disruptions linked to the pandemic outbreak [10]. While global supply chains are in chaos due to ongoing disruptions and are facing a unique set of challenges in resuming normal operations, one of the most affected segments is the 'vulnerable workers' in the 
global South: factory workers in lower- and middle-income countries who are one of the major contributors to global production networks.

The impacts of COVID-19 exacerbated the situation of global supply chain workers in developing economies [5,11], and their social sustainability, livelihood, and wellbeing continue to decline at alarming rates. Thus, the pandemic exposes and intensifies some serious risks to the lives, social wellbeing, employment, and livelihoods of vulnerable groups including female workers in global supply chains [12-14]. While the global responses to managing the ongoing pandemic primarily focused on sustaining human health and livelihood, more concerted efforts are required to safeguard the social sustainability aspects of vulnerable workers including women in the lower tiers of global supply chains $[15,16]$. Masselot and Hayes [17] (p. 57) noted that "gender issues, in particular, are at the very core of the COVID-19 pandemic". Similarly, a recent study by Pereira et al. [18] revealed that social sustainability should be the main priority of suppliers during the COVID-19 pandemic in order to go beyond meeting the predominant sustainability certification standard requirements and promoting substantive social sustainability initiatives targeting social inequalities and vulnerabilities in global supply chains.

Female workers in developing economies are the most vulnerable because of a lack of policies for the protection of women and for their involvement in low-paid jobs and the informal sector [19]. It should be mentioned that female workers dominate the global supply chain workforce. For example, in Bangladesh, the percentage of female workers is $61 \%$ who are part of global supply chain operations [20]. Thus, from a gender responsiveness and equity perspective, emerging evidence suggests that female workers are 'losing out' compared with men due to the disproportionate effects of the pandemic $[14,17,21,22]$. According to Tejani et al. [14] (p. 9), "gender-based vulnerabilities in employment persist and become magnified in the pandemic". Similarly, Brown [22], and Masselot and Hayes [17] argued that, while female workers already experienced some critical issues including inequalities in wages, gender-based violence, and harassment including sexual abuse, the pandemic has further intensified long-standing structural inequities. Findings by the Organization for Economic Cooperation and Development (OECD) [23] also indicated that violence against women has been exacerbated during the ongoing pandemic. Furthermore, a report by the International Labour Organization (ILO) revealed that, across the globe, women experienced higher employment loss than men, which will have some serious long-term implications for the livelihood and economic security of female workers [24].

For the female workforce in global supply chains, the pandemic has caused multifaceted issues that undermine women's economic participation and wellbeing and expose them to discrimination and additional vulnerabilities. Gender inequities and discrimination are mainly caused by poor health services, a lack of social protection, a precarious work environment, occupational segregation, disparity in wages and salaries, gender-based violence, and reduced access to training and education $[25,26]$, which in turn create poverty traps for women and girls [27]. Accordingly, women's participation in economic activities continues to decline, which further aggravates pre-existing gender inequities $[13,28,29]$. Similarly, public health emergencies linked to the crisis trigger women's vulnerabilities and their ability to effectively contribute to socioeconomic activities [27].

While the COVID-19 pandemic has caused some significant negative impacts on women in global supply chains, there is a paucity of research studies that have explored the effects of the pandemic on women's social sustainability. Tejani et al. [14] (p. 14) argued that, although there is "a sharp increase in unpaid care work, gender violence, and mental health problems, there are no GVC [global value chain] related studies". Thus, in this article, we focus on pressing social sustainability issues faced by women in supply chain operations of lower- and middle-income nations in the global South. As female workers are more vulnerable to discrimination and inequities in lower- and middle-income nations due to various system-related bottlenecks [30], it is worthwhile to investigate the impacts of the pandemic in the context of the developing world [27]. This echoes Nazneen and Araujo [27] (p. 106), who argued that "nations in lower- and middle-income countries in 
the global South ... are in a difficult position as they address the gender-specific impacts of the pandemic while grappling with resource constraints, inadequate public health delivery, and ineffective governance systems". Furthermore, economic and structural barriers have created some additional challenges in terms of managing gender-specific vulnerabilities and promoting gender-inclusive social sustainability enhancements in the global supply chains of developing countries [31]. Against this background, the purpose of this article is to examine the impacts of the COVID-19 pandemic on female workers in global supply chain operations and to propose potential pathways for improvement to female workers' social sustainability in present and post-COVID-19 scenarios. Hence, the research questions are as follows:

- What are the impacts of the COVID-19 pandemic on female workers in the global supply chains?

- What measures can be adopted to enhance female workforce social sustainability in global supply chains?

- How can businesses and other stakeholders collaborate to enhance social sustainability for the female workforce in global supply chains?

To achieve the purpose of this review and to answer the research questions, we conducted an extensive review of extant literature. We searched for relevant articles using electronic databases including Google Scholar, Web of Science, and Scopus to identify studies that focused on emerging issues and challenges faced by female workers in global supply chains in developing countries. Relevant articles were scrutinized and reviewed based on their significance to female workers' social sustainability issues, particularly in the garment supply chains. Accordingly, we selected articles that discussed female workers' social sustainability issues in global supply chains while excluding articles that focused solely on economic and environmental sustainability motives from the analysis. In addition to that, to fully capture the current challenges encountered by the female workforce in global supply chains, we included reports, policy documents, blogs, briefings, and other relevant materials published by international developmental organizations, research institutes, advocacy organizations, and international NGOs as well as magazine and newspaper articles. The triangulation of data sources [32,33] enabled the authors to develop an understanding of the female workers' sustainability issues and to suggest novel research findings that could potentially help policymakers, companies, governments, and international development agencies address the issues faced by female workers in global supply chains.

The remainder of the paper is structured as follows. The second section provides an overview of social sustainability. The third section presents an analysis of social sustainability issues in global supply chains. Section four considers the effects of the COVID-19 pandemic on social sustainability in global supply chains, specifically looking at women's social sustainability issues. After that, potential pathways to improving women's social sustainability in global supply chains including implications for managers, policymakers, and researchers are presented in Section five. This paper concludes with the Conclusions and Limitations section.

\section{Social Sustainability}

Social sustainability is a central pillar of sustainable development that focuses on human-centred development issues such as social progress, social equity and justice, human welfare and wellbeing, and social cohesion [34]. The goal of social sustainability is to enhance people's ability not only to survive but also to thrive collectively in individual and community realms [34]. Boström [35] (p. 4) argued that "social sustainability is an open and contested concept" that is subject to different interpretations and conceptualizations. Scholars have noted that social sustainability aspects have received very little attention compared with environmental and economic dimensions of sustainable development [36-41] as it may not be considered important or equal to predominant economic and environmental concerns $[42,43]$. 
Dempsey et al. [44] (p. 292) posited that "social sustainability is neither an absolute nor a constant ... [it] has to be considered as a dynamic concept, which will change over time (from year to year/decade to decade) in a place". Polese and Stren [45] (pp. 15-16) broadly defined social sustainability as "development (and/or growth) that is compatible with the harmonious evolution of civil society, fostering an environment conducive to the cohabitation of culturally and socially diverse groups, while at the same time encouraging social integration, with improvements in the quality of life for all segments of the population". The notion of social sustainability deals with a variety of issues including sustaining basic (e.g., food, housing, income, and security) and extended human needs (e.g., self-fulfilment); promoting intergenerational equity and justice (e.g., fair distribution of income as well as environmental 'bads' and 'goods'); fostering human rights and dignity; cultivating community development initiatives (a sense of community obligation), social cohesion, and cultural diversity; and enhancing social wellbeing and quality of life [34-36,41,46].

From a business perspective, social sustainability relates to how a firm manages its stakeholders' relationships and the impacts of its policies, decisions, and activities on society such that it contributes to advancing social aspects of sustainable development by improving human sustainability (e.g., employees' capability, health, and wellbeing) and societal sustainability (e.g., responsibility and accentuality towards consumers and communities) [37,40,47-50]. At the organizational level, social sustainability mainly deals with issues such as protection of human rights and equal opportunities; fair labour practices and working conditions; employee health, wellbeing, and quality of life; as well as learning, growth, and career development of employees $[40,46]$. First, firms have a responsibility to ensure the provision of human rights for their workers including the civil and political rights of the workers, the right to participate in collective bargaining, the right to receive equal employment opportunity and non-discriminatory treatment, avoidance of complicity, protection of vulnerable groups, protection of cultural rights, and the right to have a home life [51-53]. Second, firms are also responsible for ensuring fair labour practices and working conditions for their employees, and these issues are considered integral elements for promoting social sustainability at the workplace. This includes a safe and healthy work environment; social protection; social dialogue; abolition of modern slavery, sweatshop labour at the supply chain level [15], and child labour; and other related issues [51-53]. Third, human capital is an important consideration in promoting social sustainability at the organizational level. Preserving and developing human resources as well as nurturing human potential are imperative to enhancing social sustainability, and to achieve this end, employees should be provided with opportunities to improve their knowledge base and skills through a range of growth, training, and development initiatives $[47,48]$.

Social sustainability at the external level relates to engaging in community development initiatives and addressing the needs of a firm's direct and indirect stakeholders such as customers and suppliers [48-50,54]. According to Kok et al. [50] (p. 287), a firm has an obligation "to use its resources in ways to benefit society, through committed participation as a member of society, taking into account the society at large, and improving the welfare of society at large independently of direct gains of the company". In this regard, a firm can enhance social sustainability at the societal level by addressing three specific issues: ensuring fair operating practices, protecting consumer rights, and promoting community development initiatives. First, fair operating practices focus on fostering anti-corruption measures, ensuring responsible political involvement, and promoting social responsibility in a firm's supply chains [55]. Second, consumer rights protection relates to engaging in fair marketing practices, protecting consumer health and safety, safeguarding consumer privacy, and participating in consumer education and awareness initiatives. Third, improved community relationships and engagement are vital concerns for fostering social development and community welfare issues [41]. 


\section{The Effects of the COVID-19 Pandemic on Social Sustainability in Global Supply Chains}

\subsection{The COVID-19 Pandemic and the Vulnerable Workforce in Global Supply Chains}

Social sustainability in global supply chains has received much attention in recent years owing to pressing issues such as child and forced labour, human rights, discrimination, ethical working conditions, and equity as well as to health and safety practices [56-59] and has essentially become one of the central topics in the wake of the COVID-19 pandemic [60]. The pandemic has seriously affected the physical and mental health, livelihood, and wellbeing of workers in global supply chains [24,61-63] due to constant insecurity, fear, hunger, anxiety, and stress-related issues linked to the outbreak. The global population continues to suffer-particularly millions of global supply chain workers-from the ongoing effects of the pandemic $[24,64]$ and most of them may potentially fall into a severe poverty trap due to layoffs and redundancies $[65,66]$. It is pertinent to note that, while consumer demand for some products such as electronic devices has increased, the production of other manufacturing goods such as apparel products has sharply declined due to the pandemic, which has produced adverse impacts on millions of jobs in global supply chains, particularly in developing economies where a large portion of garment production takes place [24].

Furthermore, the COVID-19 outbreak has exposed the fundamental vulnerabilities of global supply chain networks in which certain types of companies (e.g., labour-intensive, small, and medium-sized enterprises) and workers (e.g., informal floating, daily wage, home-based, women, and migrant workers) are more susceptible to the impacts of the pandemic than others [63]. Hence, the protection of workers' health and wellbeing as well as their economic security and livelihood during the ongoing pandemic is a vital concern from a social sustainability standpoint. While it is difficult to estimate the human and economic costs associated with the pandemic, it is becoming increasingly evident that both male and female workers in global supply chains continue to encounter economic uncertainty and adversity that cause difficulty in meeting their basic needs [62] and in sustaining their livelihoods. In particular, garment supply chains are severely affected by the pandemic, and therefore, it is worthwhile to explore the pressing issues workers faced in the wake of the pandemic.

According to Tejani et al. [14] (p. 10), the garment sector is one of the most affected sectors in the global supply chain networks in which millions of workers experienced adverse consequences in the wake of the pandemic. It is argued that "garment workers desperately need assurance: they are the weakest and most vulnerable group in the supply chain and yet they are the ones presently footing the bill" [67] (p. 36). Thus, COVID-19 contributed to some painful effects on the health, wellbeing, and livelihood of garment workers in the global South $[62,64,68-70]$, and these impacts are predominantly caused by a sharp reduction in production and export of apparel products from developing countries including Bangladesh, Pakistan, Indonesia, Sri Lanka, India, and Cambodia to western markets [11]. A recent report by the Asia Floor Wage Alliance (AFWA) highlights that "the global garment industry is currently suffering from supply constraints in the form of a shortage of raw materials as well as demand constraints in the form of a decline in retail demand in Europe and North America" [11] (p. 3). Accordingly, limited demand for clothing products has caused some buyers to cancel or postpone production orders and to delay payments to supplying garment factories in developing countries [20,68,71], which has led to some distressing impacts on garment supply chain workers including losing jobs due to factory closures $[64,66,68]$, working hours being reduced substantially, or experiencing delays in wage payments [69]. Thus, economic insecurity and vulnerability caused by the pandemic led to income loss, hunger, and anxiety as well as physical and mental health issues for garment workers [62]. For example, Kabir et al. [70], in their study of readymade garment workers in Bangladesh, revealed that the COVID-19 pandemic has had a devastating impact on their health and wellbeing and has resulted in the loss of livelihood. The Bangladesh factory workers, an integral part of the global apparel 
supply chain, are mostly from low socioeconomic backgrounds and have little or no formal education, which makes them vulnerable. Kabir et al. [70] (p. 47) further asserted that "the COVID-19 pandemic will have long-lasting effects on the garment workers, especially related to their health issues, financial hardship and inability to pay for essentials such as food, and future employment opportunities".

\subsection{COVID-19 and Female Workers' Social Sustainability}

According to the ILO reports [24,72], the COVID-19 crisis has negated progress made in areas such as poverty reduction, gender equity, and decent work. In particular, the pandemic has disrupted progress made in recent years on gender equity. The pandemicinduced disruption has caused devastating impacts on both male and female workers; nonetheless, women have suffered more in terms of job loss as their unpaid working time and family commitments (e.g., childcare, home-schooling activities, and caregiving for family members who are older) increased greatly. The ILO further remarked that women's employment declined by $5 \%$ compared with men, who experienced a $3.9 \%$ reduction in employment. In addition, $90 \%$ of female workers who lost their job in 2020 left the labour force [24].

COVID-19 has created a range of challenges for female workers to effectively participate in economic activity. According to Yu et al. [73] (p. 9), the COVID-19 economic downturn has severely affected women and created "an anomaly of gender inequities". Women are overrepresented in sectors hit hard by the pandemic including food services, agriculture, tourism, business and administrative activities, manufacturing, and retail trade [72]. It is argued that "since the COVID-19 crisis has a substantial impact in specific ways on female workers, there is a possibility that some developments from these decades will be reversed, and gender inequalities intensified in the labour market" [73] (p. 10). In particular, this is likely where women are overrepresented in low-skilled labour-intensive jobs in developing countries such as Bangladesh, Ethiopia, Senegal, and Uganda [74] and low-wage segments of global supply chains [14]. Some of these countries faced massive job cuts due to the economic disruptions caused by the contraction of consumer demand products in western countries [75]. Prior studies have indicated that it is relatively difficult for women to recover from the crisis as economic revival takes much longer for them than men $[29,75]$. Moussié and Staab [29] further suggested that the pandemic has had much greater impacts on women in the informal sector, female farmers, and migrant workers than their male counterparts and that social protection programmes are lacking, which would otherwise be useful to provide a protective shield against economic shocks.

\subsection{The Current State of Female Workers' Social Sustainability in Global Supply Chains}

Female workers play an indispensable role in global supply chains and the world economy [76]. However, women continue to face critical obstacles "to achieve their potential at work, in the marketplace, and in many other aspects of life" [76] (p. 1). In the context of the developing world, female workers with limited formal education often migrate from rural localities to industrial areas mostly based in metropolitan settings. The female workforce in global supply chains are usually employed on a short-term contract or no contract, which makes them vulnerable and exposed to low wages, precarious work, and unhealthy working conditions [77]. Raworth [77] (p. 4) noted that "most [women] have no sick leave or maternity leave, few are enrolled in health or unemployment schemes and fewer still have savings for the future". In addition, the majority of women are still required to simultaneously fulfil dual responsibilities [77,78]: (i) a role as a bread winner for their families and (ii) household responsibilities including caring for children and people who are older in the family, which puts them under considerable stress and negatively affect their health and wellbeing.

Prior literature further suggests that female workers experience a multitude of serious issues in garment supply chains including occupational segregation, discrimination, long working hours, pay inequity, poor access to maternity and childcare, bullying and 
exploitation, physical and psychological abuse, sexual harassment, forced labour, and human trafficking [22,79]. In particular, "the precarious nature of women's work in global supply chains makes them especially vulnerable to sexual harassment and violence" [79]. Maria-Ariana [80] further noted that female workers in the garment supply chains encounter serious discrimination challenges such as women being forced to sign contracts to not become pregnant while working in the factory, verbal abuse, physical violence, and longer working hours. Accordingly, in recent years, there have been growing calls from the scholarly community, advocacy organizations, international development organizations, and NGOs towards building greater gender equity, inclusivity, and social sustainability in terms of protecting, supporting, and enhancing women's rights, fair economic participation, and contribution in the global supply chain operations (e.g., [22,77,79-82]).

In particular, garment supply chains employ about $60-80 \%$ of female workers globally $[21,69,83]$ who are disproportionately affected by the COVID-19 pandemic $[14,21,22]$. For example, the Bangladesh Garment Association revealed that, due to the pandemic, over 2.4 billion garment orders were cancelled or suspended by international brands, and this situation has affected more than 2 million garment workers, of which a large portion is female workers [83]. While female workers usually have limited financial means and often struggle to meet their day-to-day expenses, the pandemic contributed to extra uncertainty and complications for women in terms of financial hardship, livelihood, physical and mental health, and wellbeing [22]. Accordingly, Jalan [21] asserted that the COVID-19 pandemic has reinforced the significance of female workers in global supply chains, and increasingly many companies are recognizing that the social sustainability, wellness, and health of female workers is vital to "building back long-term resilience".

\section{Female Workers' Social Sustainability in Global Supply Chains-Implications for Managers, Policymakers, and Researchers}

The present review has several implications for practice, policy, and future research. The following sections explicate the analysis of the main gaps and opportunities for business practice, government policy, and academic research and how these issues can be addressed during and in the post-COVID era.

\subsection{Managerial Implications_-The Role of Big Brands, Multinational Corporations, and Leading Retailers}

International apparel brands, retailers, and e-retailers must consider the impacts of the COVID-19 pandemic on the vulnerable global supply chain workers working in lowerand middle-income countries [77]. In this regard, focal companies (e.g., big brands, multinational corporations (MNCs), and leading retailers) need to incorporate pressing social sustainability concerns into their business strategy $[77,84,85]$ and to actively engage and support their suppliers based in developing countries in terms of protecting workers' rights, supporting health and wellbeing initiatives, and ensuring livelihoods by offering financial support and fulfilling existing contracts and commitments. According to AFWA [11], there is a growing risk that the COVID-19 crisis could potentially cause an increase in child labour, slave labour, and human trafficking in garment supply chains, which in turn lead to pushing female workers towards other occupations such as sex work.

Kabir et al. [70] argued that it is imperative that stakeholders responsible for global supply chain operations of the garment sector such as international brands, local manufacturers, and exporters' associations should carefully reconsider social responsibility strategy to address the health, wellbeing, and livelihood of workers during the ongoing COVID-19 pandemic. Majumdar et al. [64] suggested that it is important to promote risk-sharing contracts between big brands and suppliers to address social sustainability issues. This strategy might help to improve suppliers' compliance with social sustainability standards and to prohibit them from engaging in unauthorized subcontracting of clothing manufacturing, which is one of the major causes of the lack of social sustainability in global supply chains. Furthermore, it is important that focal companies' supplier selection and order placement policies should incorporate provisions for workers' social security. Conversely, 
manufacturers and suppliers of garment products also need to ensure suitable working conditions for women by promoting women's rights including the right to join trade unions and collective bargaining, and to make efforts to eradicate prevailing discrimination and biases against women [77].

Prior supply chain sustainability literature suggests that focal companies are increasingly expected to address the social issues in global supply chains by internalizing international sustainability standards and guidelines [67]. Therefore, it is imperative that, during the ongoing pandemic and in the post-COVID world, focal companies make extra efforts to alleviate the adverse impacts of the pandemic and to go beyond the business-as-usual approach by incorporating human-oriented support measures to effectively address critical social sustainability challenges. With regard to economic insecurity and livelihood issues faced by global supply chain workers in lower- and middle-income countries, it is important that big brands not only honour their economic commitments through carrying out current supply contracts and executing timely social protection initiatives for their suppliers but also search for new ways to financially support workers employed in lowand medium-income countries [67]. According to the Clean Clothing Campaign [67], focal companies must provide financial support to their suppliers through a range of initiatives including unemployment insurance cover and emergency relief funds to support workers' incomes during this crisis. Leitheiser et al. [20] argued that well-coordinated, dedicated efforts are required by all important actors to protect the health, wellbeing, and livelihood of vulnerable supply chain workers.

Furthermore, focal companies need to ensure that the rights of female workers and other vulnerable groups including immigrant workers are fully protected during this crisis. To this end, focal companies need to collaborate with their employees, industry partners, government agencies, trade associations, advocacy groups, and other stakeholders [62,83] to establish strategic options through which the livelihood, health, and social wellbeing of the female workers are safeguarded. In a similar vein, Jalan [21] suggested that companies need to demonstrate social responsibility concerning their supply chain workers by investing in social initiatives that promote health, wellbeing, and social sustainability for female workers. To achieve this, companies need to support female workers and other vulnerable employees by making them more resilient in terms of coping with future crises [76]. Thus, the ongoing pandemic presents a unique opportunity for big brands and their supply chain network partners to re-examine their social sustainability issues and to develop more effective response strategies through which the health and wellbeing, livelihood, and overall social sustainability of female workers and other vulnerable employees can be protected.

\subsection{Policy Implications - The Role of Governments}

Government support and timely intervention can play a significant role in assisting workers and supply chain companies in lower- and middle-income countries grappling with the effects of the pandemic.

Governments-both in the North and South-need to enforce international labour standards and best practice guidelines concerning social sustainability to protect women's rights and to ensure adequate working conditions for women to effectively help address issues such as poverty, gender equity, and the overall wellbeing of women in the workforce [77]. Pereira et al. [18] argued that, while government support is instrumental for companies operating in lower- and middle-income countries to address the impacts of the pandemic, timely and effective support was mostly lacking concerning social issues. Hence, public policymakers need to acknowledge governments' central role in enhancing social sustainability and to develop policies that can assist companies in the development and implementation of effective recovery plans. In their study, Karmaker et al. [86] (p. 411) suggest thated "financial support from the government as well as from the supply chain partners is required to tackle the immediate shock on SCS [sustainable supply chains] due to COVID-19". 
Additionally, a range of policy tools and instruments can be utilized through which governments can support companies and employees to effectively manage the social impacts of the pandemic. For instance, to recover from the economic impacts of the pandemic, companies and suppliers in developing economies need not only government assistance, social protection, incentives, and financial support packages but also continued support from various supply chain partners according to their financial strength and capacity $[10,86]$. In addition, financial relief packages, wage subsidies for workers, new credit line facilities and interest-free loans for small and medium enterprises, tax relief, and other incentives could help companies and their workers recover quickly from the aftershocks of the pandemic $[49,61,62]$. "Supporting enterprises and workers through this transition will be one of the main tasks of policymakers in the years to come. Social dialogue between governments, enterprises, and workers is needed to find sustainable solutions for helping enterprises and workers navigate through this unprecedented time" [69] (p. 16). In particular, social sustainability-oriented solutions should be developed in an inclusive way so that these solutions address the needs of all workers including women who hold a significant share of employment in the garment supply chains.

\subsection{Multi-Stakeholder Collaboration for Female Workforce Social Sustainability Recovery}

Multi-stakeholder collaborations are central for sustainable development [59,78,85,87-89] to enhance female workers' social sustainability in global supply chains. "Collaboration provides learning and insight into what is working, it offers an essential way to overcome common barriers and allow companies to draw on diverse expertise to develop and scale innovative solutions" [76] (p. 41). The social sustainability and livelihood of female workers in global supply chains must be ensured by powerful brands, government support, international development organizations, and other stakeholders using a collaborative approach. It is vital that governments, big brands, and other stakeholders fully understand the impacts of the COVID-19 pandemic on the women in the workforce and devise appropriate policy measures that could help build socially sustainable and gender-sensitive recovery [90]. Institutional investors-shareholders and pension funds-have a key role in enhancing social sustainability in global supply chains including women's empowerment and human rights. These institutions can use their influence and mandate that investment markets promote socially sustainable supply chain practices in line with international labour standards [77] that are essential to developing healthy and resilient supply chains [76]. In addition to the main stakeholders in global supply chains, multilateral banks, and national and international financial institutions such as the IMF and World Bank need to advocate for workers' rights including women and vulnerable groups as this could enable achieving important international development goals including poverty reduction, good health and wellbeing, decent work and economic growth, and gender equity. Similarly, consumers can also influence big brands and MNCs can address their ethical responsibility beyond their intra-organizational operations and take concrete measures to support workers' rights through incorporating social sustainability in their sourcing and procurement decisions [77].

Jackson et al. [69] posited that the disproportionate effects of the pandemic on the garment sector have highlighted that manufacturing firms in developing countries have inadequate finances and resources to effectively address the social sustainability challenges posed by the crisis. For instance, workers in developing countries have limited access to health and social protection coverage. Thus, "in the aftermath of the crisis, greater efforts will be necessary to tackle decent work deficits in GSCs [global supply chains], ideally through multi-stakeholder approaches and social dialogue involving all firms within the supply chain, governments, and the social partners". In addition, developing countries must learn from the crisis and diversify their "economies away from an over-reliance on export-led growth towards more sustainable and inclusive structural transformation". Furthermore, supplier companies and brands might also consider the support and latest guidelines provided by the ILO's International Finance Corporation 
Better Work Programme to address the impacts of the pandemic [69]. Thus, it is imperative that national governments, civil society organizations, international development organizations, employers, trade associations, and most importantly workers collaborate with other key stakeholders and engage in social dialogue to determine effective and enduring solutions to social sustainability issues faced by female supply chain workers in developing nations [79]. Jackson et al. [69], and Yost and Moffat [83] also suggested that brands and their suppliers, governments, garment associations, and labour unions need to engage in social dialogue to develop and implement social sustainability recovery strategies. Conversely, Majumdar et al. [64] highlighted the importance of NGOs' and labour unions' participation in promoting social sustainability and the positive impacts of social initiatives to reach the grassroots level.

\subsection{Future Research Agenda and Implications}

There are several research avenues to be investigated in future studies. First, emerging evidence suggests that female workers face multidimensional socioeconomic challenges during the ongoing pandemic that produce adverse impacts on them and their families including children's sustenance and their future development. Thus, it is important to examine the role of big brands and MNCs in addressing these challenges and how focal companies might govern and support producers in developing countries such as promoting social sustainability during and in post-COVID-19 scenarios. Second, manufacturers in the global South are key players directly engaging with and responsible for managing supply chain workers both within their factories and in the lower supply chain tiers. Thus, it is pertinent to investigate how manufacturers can support the livelihood and wellbeing of their workers, including women in the workforce, to survive during the ongoing pandemic and to recover and actively contribute to their economic and social lives in the post-COVID-19 world. Third, while governments have introduced a range of shortterm measures such as financial support packages to support garment companies and to protect employees in developing countries, policymakers should also think about long-term recovery strategies and how these strategies can be implemented in a resource-constrained world. Therefore, future research could potentially explore the effectiveness and viability of long-term policy measures to deal with the impacts of the COVID-19 pandemic on vulnerable workers including women and to enhance overall social sustainability in the garment sector in years to come. Fourth, international development agencies and civil society organizations continue to advocate the significance of women's social sustainability in global supply chains; nonetheless, it is becoming more obvious that old solutions might be less effective, and thus, novel ways must be explored to overcome critical yet evolving social sustainability challenges posed by the pandemic. Accordingly, scholars could explore new advocacy tools, social sustainability approaches, and supply chain-specific initiatives that could enable big brands, governments, and manufacturers to effectively address social sustainability issues in global supply chains during the pandemic and in the post-COVID19 era. Another area of research is the investigation of how multi-stakeholder collaboration could be further enhanced to mitigate women's issues in the global supply chain. Thus, we suggest to scholars to explore the current relationships between various stakeholders in the global supply chain and to identify areas of failure as well as to suggest critical areas of improvement to reduce female workers' suffering in this sector.

\section{Conclusions}

The COVID-19 pandemic has caused an unprecedented threat to the human health, wellbeing, and livelihoods of the global population. While the pandemic has affected almost all major sectors of the global economy, female workers in lower- and middleincome countries are one of the most affected groups. Against this background, in this review article, we investigated the effects of the COVID-19 pandemic on female workforce social sustainability and wellbeing in global supply chains. To this end, we conducted an extensive review of academic literature, reports published by international developmental 
organizations, and contemporary narratives on female workers' social sustainability in global supply chains. We particularly focused on emerging challenges faced by female workers in lower- and middle-income countries in global supply chains during the ongoing COVID-19 pandemic. Based on a critical analysis of the current scholarship as well as reports and briefings published by international organizations and female advocacy groups, this article provides fresh insights concerning the issues faced by the female workforce in developing economies in the wake of the COVID-19 pandemic. Our analysis suggests that the pandemic has exacerbated women's inequities in global supply chains and that concerted efforts are needed from all stakeholders to build gender-inclusive and socially sustainable supply chains. Thus, building on the current findings, the authors proposed some potential pathways to promoting female workforce social sustainability and wellbeing in global supply chains. In addition, the article offers some important guidelines for managerial practices and policy development to enhance women's social sustainability both during the ongoing pandemic and in a post-COVID world.

While this article makes novel contributions to the extant supply chain sustainability literature by demonstrating the impacts of the COVID-19 pandemic on female workforce social sustainability in the global supply chain operations, it has some limitations. First, the findings are mainly based on the synthesis and analysis of the global supply chain sustainability literature, with no primary data collected (i.e., data were obtained exclusively from secondary sources including academic articles and policy reports), which makes it limited in terms of drawing conclusions on a broader population. This provides an opportunity to scholars to empirically investigate female workers' social sustainability issues in global supply chains using qualitative methods such as qualitative interviews, case studies, and focus groups as well as quantitative methods such as survey research. Second, we mainly focused on female workers' social sustainability issues in the garment supply chain. Accordingly, our findings are limited in scope in terms of other challenges that female workers confront in developing countries in other sectors such as agriculture and horticulture, tourism, and electronics, where female workers face critical challenges including discrimination, child labour, poor access to maternity rights and childcare, unsafe working conditions, sexual harassment and violence, extreme poverty, gender inequities, as well as occupational segregation and exploitation [91].

Author Contributions: Conceptualization, A.S. and G.E.; writing-original draft preparation, A.S.; writing-review and editing; A.S. and G.E. All authors have read and agreed to the published version of the manuscript.

Funding: This research received no external funding.

Institutional Review Board Statement: Not applicable.

Informed Consent Statement: Not applicable.

Data Availability Statement: Not applicable.

Conflicts of Interest: The authors declare no conflict of interest.

\section{References}

1. Leal Filho, W.; Brandli, L.L.; Lange Salvia, A.; Rayman-Bacchus, L.; Platje, J. COVID-19 and the UN sustainable development goals: Threat to solidarity or an opportunity? Sustainability 2020, 12, 5343. [CrossRef]

2. CIPS. What Is a Global Supply Chain? Available online: https://www.cips.org/knowledge/procurement-topics-and-skills/sup ply-chain-management/global-supply-chains / (accessed on 6 November 2021).

3. Manuj, I.; Mentzer, J.T. Global supply chain risk management strategies. Int. J. Phys. Distrib. Logist. Manag. 2008, 38, 196-223. [CrossRef]

4. Manuj, I.; Mentzer, J.T. Global supply chain risk management. J. Bus. Logist. 2008, 29, 133-155. [CrossRef]

5. ILO. The Effects of COVID-19 on Trade and Global Supply Chains; International Labour Organization: Geneva, Switzerland, 2020.

6. Harapko, S. How COVID-19 Impacted Supply Chains and What Comes Next. Available online: https://www.ey.com/en_gr/s upply-chain/how-covid-19-impacted-supply-chains-and-what-comes-next (accessed on 26 October 2021). 
7. Ellyatt, H. Supply Chain Chaos Is Already Hitting Global Growth. And It's about to Get Worse. CNBC LLC, 2021. Available online: https:/ / www.cnbc.com/2021/10/18/supply-chain-chaos-is-hitting-global-growth-and-could-get-worse.html (accessed on 1 November 2021).

8. Friesen, G. No End in Sight for the COVID-led Global Supply Chain Disruption. Forbes, 2021. Available online: https://www.forbes .com/sites/garthfriesen/2021/09/03/no-end-in-sight-for-the-covid-led-global-supply-chain-disruption/?sh=240d3a4a3491 (accessed on 23 October 2021).

9. Wang, C.; Curran, E. The World Economy's Supply Chain Problem Keeps Getting Worse. Bloomberg, 2021. Available online: https:/ / www.bloomberg.com/markets/fixed-income(accessed on 15 September 2021).

10. Rajak, S.; Mathiyazhagan, K.; Agarwal, V.; Sivakumar, K.; Kumar, V.; Appolloni, A. Issues and analysis of critical success factors for the sustainable initiatives in the supply chain during COVID-19 pandemic outbreak in India: A case study. Res. Transp. Econ. 2021, 101114. [CrossRef]

11. Asia Floor Wage Alliance. The Emperor Has No Clothes. Garment Supply Chains in the Time of Pandemic. Available online: https:/ / respect.international/wp-content/uploads/2020/06/THE-EMPEROR-HAS-NO-CLOTHES-GARMENT-SU PPLY-CHAINS-IN-THE-TIME-OF-PANDEMIC.pdf (accessed on 6 November 2021).

12. Mendez, R. The Pandemic, Supply Chains and Gendered Impacts: Lessons for Response and Adaptation by Sustainability Systems. Available online: https://www.isealalliance.org/sustainability-news/pandemic-supply-chains-and-gendered-impacts (accessed on 20 October 2021).

13. Taylor, P.; McCarthy, M. Building a Better World: The Crisis and Opportunity of Covid-19; Institute of Development Studies: Brighton, UK, 2021.

14. Tejani, S.; Fukuda-Parr, S. Gender and Covid-19: Workers in global value chains. Int. Labour Rev. 2021. [CrossRef]

15. Govindan, K.; Shaw, M.; Majumdar, A. Social sustainability tensions in multi-tier supply chain: A systematic literature review towards conceptual framework development. J. Clean. Prod. 2021, 279, 123075. [CrossRef]

16. Bahn, K.; Cohen, J.; van der Meulen Rodgers, Y.A. A feminist perspective on COVID-19 and the value of care work globally. Gend. Work. Organ. 2020, 27, 695-699. [CrossRef]

17. Masselot, A.; Hayes, M. Exposing gender inequalities: Impacts of covid-19 on Aotearoa I New Zealand employment. N. Z. J. Employ. Relat. 2020, 45, 57-69.

18. Pereira, M.M.O.; Silva, M.E.; Hendry, L.C. Supply chain sustainability learning: The COVID-19 impact on emerging economy suppliers. Supply Chain. Manag. Int. J. 2021. [CrossRef]

19. Sultana, H.; Fatima, A. Factors influencing migration of female workers: A case of Bangladesh. J. Dev. Migr. 2017, 7, 1-17. [CrossRef]

20. Leitheiser, E.; Hossain, S.; Sen, S.; Tasnim, G.; Moon, J.; Steen Knudsen, J.; Rahman, S. Early Impacts of Coronavirus on BANGLADESH Apparel Supply Chains RISC Briefing 2020. Available online: https://research-api.cbs.dk/ws/portalfiles/porta 1/60550960/Risc_report_impacts_of_coronavirus_on_bangladesh_rmg_1.pdf (accessed on 15 July 2021).

21. Jalan, S. What Covid-19 Means for Women in Global Supply Chains-And How Companies Can Take Action. 2020. Available online: https:/ / unfoundation.org/blog/post/what-covid-19-means-for-women-in-global-supply-chains-and-how-compani es-can-take-action/ (accessed on 25 October 2021).

22. Brown, G. Women garment workers face huge inequities in global supply chain factories made worse by COVID-19. J. Environ. Occup. Health Policy 2021, 10482911211011605. [CrossRef]

23. OECD. Violence against Women Has Increased during the Pandemic: Number of Female Victims. 2021. Available online: https:/ / doi-org.ezproxy.massey.ac.nz/10.1787/9d1c4f35-en (accessed on 6 November 2021).

24. ILO. COVID-19 and the World of Work. Updated Estimates and Analysis; International Labour Organization: Geneva, Switzerland, 2021.

25. Franck, A.; Prapha, A. Not in This Together: How Supermarkets Became Pandemic Winners While Women Workers Are Losing out; Oxfam: Nairobi, Kenya, 2021.

26. Beghini, V.; Cattaneo, U.; Pozzan, E. A Quantum Leap for Gender Equality: For a Better Future of Work for All; International Labour Organization: Geneva, Switzerland, 2019.

27. Nazneen, S.; Araujo, S. Building back better, gender equality, and feminist dilemmas. IDS Bull. 2021, 52. [CrossRef]

28. Milliken, F.J.; Kneeland, M.K.; Flynn, E. Implications of the COVID-19 pandemic for gender equity issues at work. J. Manag. Stud. 2020, 27, 1767-1772. [CrossRef]

29. Moussié, R.; Staab, S. Three Ways to Contain COVID-19's Impact on Informal Women Workers. Available online: https:// data.u nwomen.org/features/three-ways-contain-covid-19s-impact-informal-women-workers (accessed on 10 September 2021).

30. Chattu, V.K.; Yaya, S. Emerging infectious diseases and outbreaks: Implications for women's reproductive health and rights in resource-poor settings. Reprod. Health 2020, 17, 43. [CrossRef] [PubMed]

31. Cameron, E.C.; Hemingway, S.L.; Cunningham, F.J.; Jacquin, K.M. Global Crises: Gendered Vulnerabilities of Structural Inequality, Environmental Performance, and Modern Slavery. Human Arenas 2021, 4, 391-412. [CrossRef]

32. Bryman, A.; Bell, E. Business Research Methods; Oxford University Press: Oxford, UK, 2007.

33. Creswell, J.W. Research Design: Qualitative, Quantitative, and Mixed Methods Approaches, 3rd ed.; Sage Publication Inc.: Thousand Oaks, CA, USA, 2009. 
34. Magis, K.; Shinn, C. Emergent principles of social sustainability. In Understanding the Social Dimension of Sustainability; Routledge: London, UK, 2008; pp. 31-60.

35. Boström, M. A missing pillar? Challenges in theorizing and practicing social sustainability: Introduction to the special issue. Sustain. Sci. Pract. Policy 2012, 8, 3-14. [CrossRef]

36. McKenzie, S. Social Sustainability: Towards Some Definitions; Hawke Research Institute University of South Australia: Magill, SA, Australia, 2004; Available online: https:/ / www.unisa.edu.au/siteassets/episerver-6-files/documents/eass/hri/working-papers /wp27.pdf (accessed on 6 November 2021).

37. Sajjad, A.; Shahbaz, W. Mindfulness and social sustainability: An integrative review. Soc. Indic. Res. 2020, 150, 73-94. [CrossRef]

38. Missimer, M.; Robèrt, K.-H.; Broman, G. A strategic approach to social sustainability-Part 2: A principle-based definition. J. Clean. Prod. 2017, 140, 42-52. [CrossRef]

39. Bebbington, J.; Dillard, J. Social sustainability: An organizational-level analysis. In Understanding the Social Dimension of Sustainability; Routledge: London, UK, 2008; pp. 173-189.

40. Ajmal, M.M.; Khan, M.; Hussain, M.; Helo, P. Conceptualizing and incorporating social sustainability in the business world. Int. J. Sustain. Dev. World Ecol. 2018, 25, 327-339. [CrossRef]

41. Hutchins, M.J.; Sutherland, J.W. An exploration of measures of social sustainability and their application to supply chain decisions. J. Clean. Prod. 2008, 16, 1688-1698. [CrossRef]

42. Cuthill, M. Strengthening the 'social'in sustainable development: Developing a conceptual framework for social sustainability in a rapid urban growth region in Australia. Sustain. Dev. 2010, 18, 362-373. [CrossRef]

43. Davidson, M. Social sustainability: A potential for politics? Local Environ. 2009, 14, 607-619. [CrossRef]

44. Dempsey, N.; Bramley, G.; Power, S.; Brown, C. The social dimension of sustainable development: Defining urban social sustainability. Sustain. Dev. 2011, 19, 289-300. [CrossRef]

45. Polese, M.; Stren, R. The Social Sustainability of Cities: Diversity and Management of Change; University of Toronto Press: Toronto, ON, Canada, 2000.

46. Littig, B.; Griessler, E. Social sustainability: A catchword between political pragmatism and social theory. Int. J. Sustain. Dev. 2005, 8, 65-79. [CrossRef]

47. Osranek, R.; Zink, K.J. Corporate human capital and social sustainability of human resources. In Sustainability and Human Resource Management; Springer: Berlin/Heidelberg, Germany, 2014; pp. 105-126.

48. Dyllick, T.; Hockerts, K. Beyond the business case for corporate sustainability. Bus. Strategy Environ. 2002, 11, 130-141. [CrossRef]

49. Gladwin, T.; Krause, T.S.; Kennelly, J. Beyond eco-efficiency: Towards socially sustainable business. Sustain. Dev. 1995, 3, 35-43. [CrossRef]

50. Van der Wiele, T.; Kok, P.; McKenna, R.; Brown, A. A corporate social responsibility audit within a quality management framework. J. Bus. Ethics 2001, 31, 285-297. [CrossRef]

51. Weissbrodt, D.; Kruger, M. Norms on the responsibilities of transnational corporations and other business enterprises with regard to human rights. Am. J. Int. Law 2003, 97, 901-922. [CrossRef]

52. Arnold, D. Transnational corporations and the duty to respect basic human rights. Bus. Ethics Q. 2010, 20, 371-399. [CrossRef]

53. Ruggie, J. Protect, respect and remedy: A framework for business and human rights. Innov. Technol. Gov. Glob. 2008, 3, 189-212. [CrossRef]

54. Snider, J.; Hill, R.P.; Martin, D. Corporate social responsibility in the 21st century: A view from the world's most successful firms. J. Bus. Ethics 2003, 48, 175-187. [CrossRef]

55. Mani, V.; Gunasekaran, A. Four forces of supply chain social sustainability adoption in emerging economies. Int. J. Prod. Econ. 2018, 199, 150-161. [CrossRef]

56. Mani, V.; Agrawal, R.; Sharma, V. Social sustainability in the supply chain: Analysis of enablers. Manag. Res. Rev. 2015, 38, 1016-1042. [CrossRef]

57. Mani, V.; Agarwal, R.; Gunasekaran, A.; Papadopoulos, T.; Dubey, R.; Childe, S.J. Social sustainability in the supply chain: Construct development and measurement validation. Ecol. Indic. 2016, 71, 270-279. [CrossRef]

58. Nath, S.D.; Eweje, G.; Sajjad, A. The hidden side of sub-supplier firms' sustainability-An empirical analysis. Int. J. Oper. Prod. Manag. 2020, 40, 1771-1799. [CrossRef]

59. Yawar, S.A.; Seuring, S. Management of social issues in supply chains: A literature review exploring social issues, actions and performance outcomes. J. Bus. Ethics 2017, 141, 621-643. [CrossRef]

60. Sajjad, A. The COVID-19 pandemic, social sustainability and global supply chain resilience: A review. Corp. Gov. Int. J. Bus. Soc. 2021, 21, 1142-1154. [CrossRef]

61. van Barneveld, K.; Quinlan, M.; Kriesler, P.; Junor, A.; Baum, F.; Chowdhury, A.; Junankar, P.N.; Clibborn, S.; Flanagan, F.; Wright, C.F. The COVID-19 pandemic: Lessons on building more equal and sustainable societies. Econ. Labour Relat. Rev. 2020, 31, 133-157. [CrossRef]

62. Flores, L.; Shields, L. I Can Hardly Sustain My Family: Understanding the Human Cost of the COVID-19 Pandemic for Workers in the Supply Chain; BSR: San Francisco, CA, USA, 2020.

63. Alam, S.; Adnan, Z.H.; Baten, M.A.; Bag, S. Assessing vulnerability of informal floating workers in Bangladesh before and during COVID-19 pandemic: A multi-method analysis. Benchmarking Int. J. 2021. [CrossRef] 
64. Majumdar, A.; Shaw, M.; Sinha, S.K. COVID-19 debunks the myth of socially sustainable supply chain: A case of the clothing industry in South Asian countries. Sustain. Prod. Consum. 2020, 24, 150-155. [CrossRef]

65. Caballero-Anthony, M. Global Health Security: Lessons from COVID-19 in East Asia. 2021. Available online: https://www.peac eful-competition.org/pub/bjxk52wm/release/1?readingCollection=3bbd6f2c (accessed on 28 October 2021).

66. Sakamoto, M.; Begum, S.; Ahmed, T.J.S. Vulnerabilities to COVID-19 in Bangladesh and a reconsideration of sustainable development goals. Sustainability 2020, 12, 5296. [CrossRef]

67. Clean Clothing Campaign. Un (der) Paid in the Pandemic: An Estimate of What the Garment Industry Owes Its Workers; Clean Clothing Campaign: Amsterdam, The Netherlands, 2020.

68. Anner, M. Abandoned? The Impact of Covid-19 on Workers and Businesses at the Bottom of Global Garment Supply Chains Center for Global Workers' Rights Research Report. 2020. Available online: https://www.workersrights.org/wp-content/uploa ds /2020/03/Abandoned-Penn-State-WRC-Report-March-27--2020.pdf (accessed on 10 May 2020).

69. Jackson, J.L.; Judd, J.; Viegelahn, C. The Supply Chain Ripple Effect: How COVID-19 is Affecting Garment Workers and Factories in Asia and the Pacific; International Labour Organization: Bangkok, Thailand, 2020.

70. Kabir, H.; Maple, M.; Usher, K. The impact of COVID-19 on Bangladeshi readymade garment (RMG) workers. J. Public Health 2021, 43, 47-52. [CrossRef]

71. World Bank. South Asia Economic Focus; World Bank: Washington, DC, USA, 2021.

72. ILO Women. UN Secretary-General's Policy Brief: The Impact of Covid-19 on Women; UN Woman: New York, NY, USA, 2020.

73. Yu, Z.; Razzaq, A.; Rehman, A.; Shah, A.; Jameel, K.; Mor, R. Disruption in global supply chain and socio-economic shocks: A lesson from COVID-19 for sustainable production and consumption. Oper. Manag. Res. 2021, 1-16. [CrossRef]

74. ILO. COVID-19: Tackling the Jobs Crisis in the Least Developed Countries; International Labour Organization: Geneva, Switzerland, 2020.

75. ILO. ILO Monitor: COVID-19 and the World of Work, 5th ed.; Updated Estimates and Analysis; International Labour Organization: Geneva, Switzerland, 2020.

76. Davis-Pluess, J.; Pruzan-Jorgensen, P. Women's Empowerment in Global Value Chains: A Framework for Business Action to Advance Women's Health, Rights, and Wellbeing; BSR: San Francisco, CA, USA, 2017.

77. Raworth, K. Trading Away Our Rights: Women Working in Global Supply Chains; Oxfam: Nairobi, Kenya, 2004.

78. Pike, K.; English, B. And roses too: How "Better Work" facilitates gender empowerment in global supply chains. Gend. Work. Organ. Environ. 2021. [CrossRef]

79. Morris, J.; Pillinger, J. Gender-Based Violence in Global Supply Chains: Resource Kit; Fair Wear Foundation and International Training Centre-ILO: Turin, Italy, 2016.

80. Maria-Ariana, D. Brief considerations on the rights and working conditions of employees in the textile and clothing industry globally and in Romania. Ann. Univ. Oradea Fascicle Text. Leatherwork 2017, 18, 177-182.

81. Kabeer, N.; Mahmud, S. Globalization, gender and poverty: Bangladeshi women workers in export and local markets. J. Int. Dev. 2004, 16, 93-109. [CrossRef]

82. Prieto-Carrón, M. Women workers, industrialization, global supply chains and corporate codes of conduct. J. Bus. Ethics 2008, 83, 5-17. [CrossRef]

83. Yost, M.; Moffat, E. Women in Supply Chains: On the Frontlines of COVID-19's Impact. Available online: https://www.bsr.org/ en/our-insights/blog-view/women-in-supply-chains-on-the-frontlines-of-covid-19-impact (accessed on 14 December 2020).

84. Sajjad, A.; Eweje, G.; Tappin, D. Managerial perspectives on drivers for and barriers to sustainable supply chain management implementation: Evidence from New Zealand. Bus. Strategy Environ. 2020, 29, 592-604. [CrossRef]

85. Sajjad, A.; Eweje, G. Corporate social responsibility in Pakistan: Current trends and future directions. In Corporate Social Responsibility and Sustainability: Emerging Trends in Developing Economies; Emerald Group Publishing Limited: Bingley, UK, 2014; pp. 163-187.

86. Karmaker, C.L.; Ahmed, T.; Ahmed, S.; Ali, S.M.; Moktadir, M.A.; Kabir, G. Improving supply chain sustainability in the context of COVID-19 pandemic in an emerging economy: Exploring drivers using an integrated model. Sustain. Prod. Consum. 2021, 26, 411-427. [CrossRef]

87. Eweje, G.; Sajjad, A.; Nath, S.D.; Kobayashi, K. Multi-stakeholder partnerships: A catalyst to achieve sustainable development goals. Mark. Intell. Plan. 2020, 39, 186-212. [CrossRef]

88. Raimo, N.; Rella, A.; Vitolla, F.; Sánchez-Vicente, M.-I.; García-Sánchez, I.-M. Corporate social responsibility in the COVID-19 pandemic period: A traditional way to address new social issues. Sustainability 2021, 13, 6561. [CrossRef]

89. Mathiyazhagan, K.; Agarwal, V.; Appolloni, A.; Saikouk, T.; Gnanavelbabu, A. Integrating lean and agile practices for achieving global sustainability goals in Indian manufacturing industries. Technol. Forecast. Soc. Chang. 2021, 171, 120982. [CrossRef]

90. ILO. Gendered Impacts of COVID-19 on the Garment Sector; International Labour Organization: Bangkok, Thailand, 2020.

91. ILO. Global Supply Chains: Where Do Women Work and under What Conditions? Available online: https://gbv.itcilo.org/index .php/briefing/show_paragraph/id/40.html (accessed on 9 November 2021). 